Ackee and saltfish vs. amalá con quimbombó? A note on Sidney Mintz' contribution to the historical anthropology of African American cultures

\title{
Stephan Palmié
}

\section{OpenEdition}

\section{Journals}

Electronic version

URL: https://journals.openedition.org/jsa/2988

DOI: 10.4000/jsa.2988

ISSN: 1957-7842

Publisher

Société des américanistes

\section{Printed version}

Date of publication: 5 December 2005

Number of pages: 89-122

ISSN: 0037-9174

\section{Electronic reference}

Stephan Palmié, "Ackee and saltfish vs. amalá con quimbombó? A note on Sidney Mintz' contribution to the historical anthropology of African American cultures", Journal de la Société des américanistes [Online], 91-2 | 2005, Online since 10 June 2010, connection on 06 September 2022. URL: http:// journals.openedition.org/jsa/2988 ; DOI: https://doi.org/10.4000/jsa.2988 


\title{
ACKEE AND SALTFISH VS. AMALÁ CON QUIMBOMBÓ? A NOTE ON SIDNEY MINTZ' CONTRIBUTION TO THE HISTORICAL ANTHROPOLOGY OF AFRICAN AMERICAN CULTURES
}

\author{
Stephan PALMIÉ *
}

\begin{abstract}
In the spirit of Sidney Mintz' contribution to African American historical anthropology, this essay examines theories allocating differential explanatory weight to African cultural continuities and New World social conditions in the historical development of African American cultures through the lens of a set of culinary allegories built around two Caribbean dishes. Specifically, I argue that the opposition recently voiced by some Africanist historians against the so-called « rapid early synthesis » model developed by Sidney Mintz and Richard Price not just misinterprets the theoretical issues at hand, but foregrounds highly problematic, and ultimately ahistorical, notions of " Africanity ». Contrasting Cuban and North American conceptual linkages between " Africanity » and " racial identity », and surveying the emergent North American literature on " culinary Pan-Africanism » in light of theories of cultural property, I suggest that it is time we transcended the terms in which the debate between so-called « creolists " and "New Revisionists" has been framed. [Key words : historical anthropology, African American cultures, food and cuisine, race, Africanity.]
\end{abstract}

Ackee and saltfish ou amalá con quimbombó ? Note sur la contribution de Sidney Mintz à l'anthropologie historique des cultures afro-américaines. Cet article s'inscrit dans la lignée des contributions de Sidney Mintz à l'anthropologie historique afro-américaine. Par le biais de l'analyse d'allégories construites autour de deux plats antillais, sont analysées différentes théories qui accordent une influence, plus ou moins importante, aux « continuités culturelles africaines » et aux conditions sociales du Nouveau Monde dans le développement historique des cultures afro-américaines. L'article montre que les prises de position de certains africanistes, allant à l'encontre du modèle de la "synthèse rapide " développé par Sidney Mintz et Richard Price, se fondent, non seulement sur un malentendu quant aux innovations théoriques proposées par ces deux auteurs, mais aussi sur une conception de l'africanité très problématique et clairement anhistorique. En opposant les liens conceptuels entre "africanité » et "identité

* Department of Anthropology, University of Chicago, 1126 E 59th St., Chicago IL 60637, États-Unis [palmie@uchicago.edu].

Journal de la Société des Américanistes, 2005, 91-2, pp. 89-122. C Société des Américanistes. 
raciale » tels qu'ils sont élaborés à Cuba et en Amérique du Nord, et en parcourant, à la lumière des théories sur la propriété culturelle, la littérature nord-américaine sur le " panafricanisme culinaire », l'auteur propose de dépasser les termes du débat aujourd'hui imposé par les partisans des écoles "créole » et "néo-révisionniste ». [Mots clés : anthropologie historique, cultures afro-américaines, nourriture et cuisine, race, « africanité ».]

¿ Ackee and saltfish $o$ amalá con quimbombó ? Una nota sobre la contribución de Sidney Mintz a la antropología histórica de las culturas afroamericanas. En el espíritu de las contribuciones de Sidney Mintz a la antropología histórica de las culturas afroamericanas, y mediante el ejemplo de dos alegorías basadas en dos típicos platos caribeños, este ensayo contrapone teorias que enfatizan las continuidades culturales africanas contra otras que ponen el peso explicatorio en las condiciones sociales del nuevo mundo. Específicamente plantea que la reciente oposición de algunos historiadores africanistas al modelo de una « síntesis rápida y temprana » desarrollado por Sidney Mintz y Richard Price, no solamente malinterpreta los problemas teóricos involucrados en este debate, sino que también se apoya en nociones problemáticas y ahistóricas de la « africanía ». Luego de contrastar las conexiones conceptuales entre identidad racial y "africanía » en Cuba y en América del Nork, y a la luz de las teorías sobre la propriedad cultural de revisar la emergente literatura norteamericana sobre el panafricanismo culinario, este trabajo propone que ya es tiempo de que superemos los términos que han enmarcado el debate entre los llamados creolistas y los nuevos revisionistas. [Palabras claves : antropología histórica, culturas afroamericanas, antropología culinaria, raza, " africanía ».]

Kò si maggi kò sí ọbẹ where there is no Maggi, there is no sauce (Yoruba saying) ${ }^{1}$

As Sidney Mintz has taught us, thinking about food can aid us in thinking, through complex histories, wide-ranging processes of cultural change, and the unfolding and transformation of relations of domination and resistance ${ }^{2}$. Drinking heavily sweetened tea came to the emerging British working class as part and parcel of an entire, rapidly evolving package inscribing both the nutritional and cultural terms of their exploitation within the most intimate structures of everyday life (Mintz 1985). Likewise, as Mintz (e.g. 1966 ; 1970 ; 1974 ; 1995 ; 1996b) has pointed out again and again, the human chattel dragged into American plantation colonies from Africa asserted and recovered their humanity not just through violent revolt against their oppressors. Less spectacularly, but often far more significantly, they did so through seemingly insignificant attempts to gain a modicum of control over the conditions of their everyday lives : the ways they planted their provision grounds, cooked their food, nourished their children, and buried their dead in allotted garden spaces - thereby literally embedding evolving systems of kinship and descent in land over which they exercised no formal rights. 
In this essay, I propose to do something rather more modest, but also conceptually different. I will look at two Caribbean dishes not so much to illuminate their historical contexts of origin, as to discuss how we have come to think about these contexts of origin. The juxtaposition of the Jamaican ackee and saltfish with the Cuban amalá con quimbombó in the title of my contribution, thus, does not so much aim to evoke the different histories of local Caribbean cuisines, the embeddedness of specific Caribbean foods in wider Atlantic histories, or their contemporary meanings to those who consume them - all fascinating subjects that in both cases await adequate exploration ${ }^{3}$. Rather, what I would like to do is to construe these two dishes as emblematic of two basic theoretical approaches to the emergence and development of African-American cultures : one which places prime emphasis on African cultural continuities in the formation of such aggregates of knowledge and practice, while the other emphasizes the concrete historical conditions under which heterogeneous cultural forms came to integrate essentially novel collectivities - the slave societies of the New World. This may seem a somewhat frivolous endeavor - less inspired, perhaps, by Sidney Mintz' empirical rigor, and analytical sobriety, than by Fernando Ortiz (1995) magnificently bookish, and flamboyantly ironical project of casting an essay on the historical impact of tobacco and sugar on Cuban society in the form of a medieval morality play. Still, since food constitutes a prime symbolic resource for modeling other, non-culinary domains of experience and sociality, I think the many unwitting ironies apparent in the way scholars have interpreted Mintz' path-breaking theoretical contributions to the historical anthropology of African American cultures bear being scrutinized through a culinary lens. After all, if Plato likened analysis to the carving up of a roast, there is no reason why food and cuisine should not serve as a vehicle for theoretical reflections.

In teaching the origins and development of African American cultures, I have often found it useful to confront students with the few startling facts that we have about the origins of what one might call Jamaica's national breakfast dish - were it not for the fact that the prohibitive price of imported salt cod nowadays places the dish beyond the means of all but the local elite. Of course, when you are talking about the 18th century British West Indies, salt cod is anything but the luxury food it became in the second half of the 20th century, when international fishery wars demonstrated that salted North Atlantic cod was no longer a sheer unlimited source of cheap, preservable protein (Kurlansky 1997). Yet such it was, when British Caribbean planters exchanged New England cod against molasses in order to feed it to their otherwise protein-starved slaves (Sheridan 1976). Like the Spanish and Portuguese whose Old World knowledge of salt cod preparations goes back to pre-Columbian times, the British knew that salt cod made for an excellent « fringe » to a « core » of complex carbohydrates (Mintz 1985) - both nutritionally and in regards to imparting flavor to otherwise deadly bland starches. They also knew that shifting products around within their 
own imperial circuit made perfect sense in terms of mercantilist economic doctrine. How salt cod from Newfoundland and Massachussetts wound up in Caribbean cuisines, in other words, is not a mystery (Innis 1940; see also Kurlansky 1997 ; Moreno Fraginals 1986, II, p. 60, note 87). Nor, for that matter; is there much surprise about the molasses in Boston baked beans, or the popularity of the rum distilled from it ${ }^{4}$.

Still, even if we wanted to book the ubiquitous cod dishes of the Caribbean as a profit-driven transfer of basically European culinary knowledge to enslaved Africans who might have assimilated salt cod to their own conceptions of fritter-bases, or the use of smoke-dried fish in saucing starches, we would still have to solve the mystery of the Jamaican use of the reddish, pear-shaped fruit of a tree known as Blighia sapida or ackee in cod-fish preparations. For not only is the ackee tree of African origin (unlike the Polynesian breadfruit, which was brought to Jamaica by William Bligh of Bounty infamy - the botanical name of ackee appears to be based on a misattribution ${ }^{5}$ ). Ackee is also a very risky food unless you know when to eat it. Containing a highly toxic peptide, unripe ackee will kill you if eaten in sufficient quantities, and every year a few people in Jamaica die of ackee poisoning. You have to know when to pick it - it is ripe, Jamaicans say, when it begins to smile (i.e. when its skin cracks open exposing the yellow flesh and black seeds) - and that knowledge was surely not brought to Jamaica by British planters or Irish servants ${ }^{6}$.

What we get when properly soaked salt cod is gently pan-fried with onions, bell and scotch bonnet peppers, and the ripe yellow pulp of the ackee fruit, in other words, is the paradoxical transformation of geographically extremely heterogeneous ingredients and culturally no less disparate forms of culinary knowledge into an entirely unprecedented and intensely localized dish. It is not just that people elsewhere in the Caribbean think of ackee and saltfish as something emblematically Jamaican. It simply is a dish indigenous to the place Jamaica became once fully entangled in what Philip Curtin (1955) called the South Atlantic system ${ }^{7}$. Old World materials and forms of knowledge certainly are crucial to its origin. Perhaps Old World taste preferences may have been involved as well, though ackee does not seem to play much of a role in contemporary West African diets. But the history of the cultural form that is ackee and saltfish is one of New World transformation, synthesis and creativity. It is, and I hesitate to use the word, a history of creolization.

My story about ackee and saltfish is, of course, an allegorical one. And what it seeks to evoke is a way of modeling the origins of African American cultural forms for which Sidney Mintz and Richard Price's 1976 essay An anthropological approach to the Afro-American past : a Caribbean perspective (republished as The Birth of African American culture in 1992) is of crucial intellectual importance. Reacting (among other things) against the highly ahistorical tendencies to derive 
« African origins » for New World cultural forms from shortcircuiting temporally disparate ethnographic descriptions from both sides of the Atlantic, Mintz and Price forcefully argued for a rigorous historicization of African-Americanist scholarship. Most crucially, they advocated an analytical shift away from comparing seemingly free-floating units of cultural form to units of historically contextualizable social enactment. This immediately problematized the historical conditions of social re-aggregation among enslaved Africans in the New World, transforming Atlantic cultural continuities from an explanans for African American cultural forms into the explanandum. For it directed attention not only to - processually induced - discontinuities in cultural transmission, but to the role of cultural creativity and large scale ad-hoc syntheses in precipitating the institutional crystallization of such cultural forms as are observable in the Americas. Though careful not to deny the importance of Old World resources in AfricanAmerican societalization and culture building, Mintz and Price's re-statement of the problem nevertheless placed the explanatory onus squarely on the shoulders of those arguing for immediate and ethnically specific African continuities ${ }^{8}$. If Herskovits' $(1941 ; 1966)$ pioneering, though methodologically naive, approach to the African-American past had implied an imagery of erosion and fragmentation of identifiable transplanted African units, Mintz and Price emphasized the fusion of fragments into essentially new cultural entities. What came into view, thus, were processes of cultural change, informed both by Old World cultural resources and the exigencies of the particular New World " social arenas » in which they were put to use.

This so-called « rapid early synthesis » or « creolization » model was taken up primarily by historians of North American slavery, and strongly influenced some of the best social histories of slavery of the 1970s and 1980s (from Gutman 1976 through Scott 1985, Kulikoff 1986 and the conference volumes edited by Berlin and Morgan 1991, and McGlynn and Drescher 1992 to mention just a few outstanding examples). But all the 1980s anthropological rhetoric about practice, agency, and « historic turns » notwithstanding, Mintz and Price's essay remained largely unread in our own discipline. In part this may have been due to its relatively obscure initial publication venue. But since historians did manage to get a hold of it, one suspects that one important reason for this curious neglect of Mintz and Prices's contribution lay in the longstanding marginality of Caribbean ethnography to the thrust of anthropological theorizing. Long regarded as anything but a "prestige zone of theory » (Abu Lughod 1989) for a discipline founded on the naturalistic fiction of the fundamental ab-originality, discrete particularity, and autonomous self-reproduction (and, hence, by implication, essential "non-westernness ») of its proper object of study, Caribbean and African American societies more generally entered the purview of American anthropology virtually by default - i.e. as a foil for the study of seemingly « artificially » induced or accelerated forms of cultural change and hybridization 
which, however, remained firmly pegged to implicit notions of previous states of " purity » (Redfield et al. 1936; Herskovits 1941). Exemplified most clearly in Herskovits's programmatic search for African origins of African American cultural «traits », such analyses, ironically began to be perceived as crudely mechanistic in our discipline precisely at the time that their political implications became subject of heated public debate in the course of the emergence and radicalization of the Black Movement in the U.S. : as black Americans began to embrace anthropologically pre-constructed versions of an African past (that black intellectuals such as W. E. B. DuBois or Carter Woodson had long sought to install in the North American public imagination), American anthropologists increasingly distanced themselves from the methodologies that had helped to generate, and lend academic caché to such constructions ${ }^{9}$. Irrespective of the methodological (rather than substantive or epistemological) thrust of Mintz and Price's argument, An anthropological approach to the Afro-American past thus seems to have been perceived as merely another contribution to an increasingly public and thoroughly politicized but, by the same token, theoretically uninteresting, and most importantly rather passé controversy about whether or to what extent genuine African continuities in the Americas could be empirically authenticated, and whether it was anthropology's job to do so (see Scott 1991) ${ }^{10}$.

This, of course, has changed dramatically in recent years - and on both accounts. While few anthropologists working in the Caribbean today can be said to be overly concerned with what Scott (1999) called a neo-Herskovitsian « verificationist agenda », the Caribbean itself has suddenly moved into the limelight of contemporary theorizing as a site of precisely the kind of historical overdetermination, fluidity and instability we now cherish as an antidote to the seemingly transparent verities and purities of yore ${ }^{11}$. Still, the recent infatuation with « things Caribbean » among anthropologists and cultural critics self-consciously positioning themselves on the vanguard of social theory thrives on a host of surprisingly unreflected assumptions. As Kevin Yelvington (2001, p. 250) has argued, the crux of the matter may well be that while American " mainstream » anthropology had once dismissed Caribbean and African American cultures more generally as inauthentic, burdened with a surfeit of turbulent history, spuriously westernized and therefore theoretically unrewarding (i.e. of interest mainly to those aiming to "do development »), the self-consciously " "new" perspectives in contemporary [i.e. late 20th century] anthropological theory such as the globalization of cultures, hybridity, transnationalism, colonialism, and political economy, which have always been the concern of AfroAmericanists, can only be presented as "new" in and through " an elision of the precedents set by Caribbean intellectuals such as Eric Williams or C.L.R. James, and anthropologists working on the Caribbean - a region that, after all, was the cradle of European overseas colonialism, a fulcrum for the development of the modern capitalist world system, and the stage for some of the most 
dramatic and violent demographic and cultural dislocations in recorded history (see Trouillot 1992).

But how ironic, then, that by the time mainstream anthropology began to discover the Caribbean under the sign of (all but unproblematic !) theories of " creolization ", " globalization ", and " transnationalism » in the early 1990s, quite a few historians - happily unfazed by the « crisis of representation » raging in their own discipline as well - were turning away from what I would like to call an ackee and saltfish model of the origins and history of African American cultures ! Led by Africanists like John Thornton (1992) and Paul Lovejoy (1997), but eagerly advocated by some historians of the U.S. South like Gwendolyn Midlo Hall (1992), Douglas Chambers (1997), or Michael Gomez (1998), what Lovejoy bills as a " new revisionism » and describes as an explicitly « Africancentric or even Afrocentric » (Lovejoy 2000, p. 1) approach targets a « creolization school » (allegedly founded by Mintz and Price) for having systematically written Africa out of the history of the New World. Lovejoy's confusing terminology to the contrary, this is by no means a critique launched from, or even originating in, the context of dissident U.S. African American cultural nationalist scholarship (e.g. Asante 1987; see Moses 1998; Howe 1998; Walker 2001). Rather; it emanates from the disciplinary core of the American historical profession where, after decades of research focused on the New World social conditions under which African American cultures emerged, neo-Herskovitsian notions about the over-riding importance of the slaves' original African « cultural identity » in such processes have, once more, gained ground in recent years ${ }^{12}$. Even historians openly skeptical of the "new revisionist » project (such as Morgan 1997 or Northup 2000) nowadays concede that they are facing an emerging "orthodoxy " which has found institutional expression in such highly visible academic venues as the UNESCO-sponsored Slave Route project, or (although less explicitly) in Harvard's W. E. B. DuBois Institute's slaving voyage database project (Eltis et al. 1999).

Given the fact that $\mathrm{I}$ have been variously classified by new revisionists as both a member and critic of the « creolization school » (Hall 1997 ; Lovejoy 2000), I do not intend to take the matter much beyond noting that one main thrust of the new revisionist critique concerns a re-valuation of the role of African ethnicity in the formation of New World identities and cultures. Centered as Mintz and Price's essay was on historical and ethnographic evidence pertaining to the - arguably rather specific - scenario of the emergence of the societies and cultures of the Suriname maroons, it is, as David Northup (2000, p. 3 ; Palmié 1993) has argued, perhaps not « surprising that some scholars have put forward different models of identity formation among enslaved Africans in the Americas $\gg{ }^{13}$. But to proceed to the assertion that the approach advocated by Mintz and Price would thrive on the " assumption that not much African history is relevant to the study of the Atlantic [world] because the enslaved population was too diverse to sustain the 
continuities of history " (Lovejoy 2000, p. 2) comes down to substituting one problematic supposition for another. For if, as Morgan (1997, p. 123) puts it, the tendency of new revisionists to equate the term « nation » (nación, nação, etc.) as evidenced in the historical record of the slave trade with twentieth century conceptions of African ethnolinguistic entities becomes the basis for arguing that such entities represented " the social force driving the development of slave life " in the New World, the nature of pre-colonial African forms of collective identification would surely constitute the ground on which such arguments might stand or fall. Yet precisely this is, by no means, an uncontroversial issue among Africanist historians and historical anthropologists. Many remain highly skeptical of the possibility of delimiting stable ethnically organized collectivities in pre-colonial Africa - and they do so both on empirical and theoretical grounds, i.e. not because we know that much Africanist ethnography misrepresented essentially colonial formations as timeless patterns of culture and sociality, but because we have become wary of the reificatory and reductionist potential of concepts such as " identity », " ethnicity ", and even " culture » ${ }^{14}$. But rather than take on the debate myself, let me resort once more to a culinary allegory.

" ¿ Has comido el amalá ? ( " have you eaten amalá ? »), my friend José Luis asked me as I stepped into the sparsely-furnished apartment in Havana's Vedado section of which he had become the proud microbrigadista-owner since I had last been to Cuba. "Because that's what la mulata [meaning his wife Cármen] is cooking for you tonight. The famous amalá con quimbombó. Just as they make it in the cabildo ${ }^{15}$ her sister cooks for in Cienfuegos ». What Cármen cooked for me that evening in the fall of 2000 was a thick cornmeal porridge rolled into dumplings and eaten with a sauce of okra stewed in a fairly standard Cuban sofrito of onions, garlic, tomatoes and mild aji peppers ${ }^{16}$. I am quite sure that José Luis and Cármen treated me to that dish because José Luis wanted to show me how far he had come since I first met him in the terrible winter of 1994-1995, when he was sharing two rooms in Centro Habana with three other adults and two children. After all, as Cármen explained, the secret to good amalá is to add lots of fat to the water and cornmeal mixture - and to this day, neither cooking oil nor lard is available for national currency ${ }^{17}$. But José Luis also wanted me to try this dish because it is strongly associated with the Afro-Cuban religion regla ocha. Amalá con quimbombó is a sacrificial food for Changó - the Cuban equivalent to the deified fourth Alafin of the Oyo Yoruba - and although neither of my friends practice regla ocha, they rightly assumed that I would like to see how this most emblematically African of Afro-Cuban foods is made ${ }^{18}$.

But what is an African or; for that matter; Afro-Cuban food? This is a question which Sidney Mintz raised some 30 years ago in his « Foreword " to Whitten and Szwed's anthology Afro-American Anthropology (Mintz 1970). It may, of course, seem commonsensical enough to point to Africans eating certain 
foods in Africa - say Fortes and Fortes' (1936), Richards' (1939), Bascom's (1951a and b), Goody's (1982), or Weiss' (1996) descriptions of Tallensi, Bemba, Yoruba, LoDaaga, or Haya cuisine - and propose that what they are eating is "African food ». But leaving aside, for the moment, the possible conceptual complication that the African foodways described by these authors all contained such New World cultigens as manioc, maize, or capsicum, the problem immediately becomes clear when we consider what conceptual operations are necessary to qualify a food eaten in a New World location as « African ». And this - or so my argument goes - is a problem relevant not only to the study of food, but any other cultural forms New World people (or their ethnographers) associate with Africa. In other words : there is not, nor can there be, anything straightforwardly indexical about attributions of Africanity to phenomena occurring in the Americas. Nor could there be. For different from, say, calling Mount Cameroon an African rock formation, or even attributing African origins to a plant like ackee, it is hard to imagine anything to which the term African-American could be meaningfully applied that is not the product of human agency and therefore of history.

But let us look at amalá con quimbombó from a new revisionist perspective nonetheless. Àmàlà is of course, a Yoruba term for a yam-flour porridge that might quite conceivably be eaten with obe ila - i.e. an okra stew perhaps not too dissimilar from what Carmen cooked for me ${ }^{19}$. That the Cuban version combines American maize with hibiscus esculentus (which probably came to the Americas from Africa rather than from its probable regions of original cultivation in South Asia and the Middle East, and may have spread to Yorubaland through Portuguese interference) ${ }^{20}$ is somewhat troubling from a new revisionist point of view. But it might well be written off along the same lines that e.g. John Thornton $(1984 ; 1988 ; 2002)$ has used to interpret some of the Catholic elements in Haitian vodou as Africanisms - i.e. as allogenic imports (whether biotic or cultural) which had taken root in certain regions of Africa so early, that they can effectively be treated as African imports to the Americas ${ }^{21}$. That Bascom's informants in Ile Ifé in the 1930s had come to assimilate cassava porridge to the term àmàlà would only strengthen such a case - as would the Afro-Cuban myth collected by Cabrera (1983, p. 468) that depicts Changó himself as the bringer of maize to Yorubaland ${ }^{22}$.

That question bracketed, however, it is ironically the dish's patently African name which - perhaps more than anything else - spoils the broth for those intent on concocting a new revisionist case, clearly marking amalá con quimbombó off, instead, as historically « of » the New World. To be sure, amala is a Yoruba word for a conceptually similar dish which enslaved Yoruba-speakers may well have brought to Cuba. Yet the Bantu-derived term quimbombó ${ }^{23}$ points towards a potentially much longer history of Western Central African-inspired okra-use in Cuba. For, while Cuba received slaves from western Central Africa as early as the 
16th century, it was only when Cuba's extremely late development as a sugar colony coincided with the wars unleashed by the increasing decline of the Oyo Yoruba state after about 1820 that large numbers of Yoruba-speaking slaves entered the island ${ }^{24}$. This is not to say that a Yoruba deity learned to eat his starches with a western Central African sauce that may have been locally known as «mwamba » or "moamba » when his enslaved worshippers arrived in $\mathrm{Cuba}^{25}$. What I do want to point out, however, is that the conjunction of the terms amalá and quimbombó make it hard to think of the dish, its name, and even the sacred uses it is put to in contemporary regla ocha as anything other than historical composites - and ones for which the New World provides a far more plausible scenario of origin than any single region of Africa. For consider this : where in Africa might someone eating okra stew with cornmeal porridge say that he or she was eating amalá and quimbombó, associate a food of that name with a deity locally known as Changó, and regard it as emblematically «African » (rather than simply a part of local or regional cuisine)?

But there is more to the matter. For while both of my Cuban hosts that evening in el Vedado certainly were of African descent, I am positive that neither of them would have laid a greater claim on amalá con quimbombó than phenotypically white Cubans initiated into the cult of the Changó. This brings us to the question about the social identity of consumer and consumed that Sidney Mintz broached more than thirty years ago (Mintz 1970). Obviously, the issue deserves fuller attention than I can give it here. But I would like to indicate how complex the matter is in the Cuban case, and then present, if in mere outline, some of the more perplexing results of the current North American trend towards the objectification of culinary knowledge and practice as racialized forms of collectively « owned » immaterial property. What I hope to illuminate is not just the plasticity of the culinary signifier, but its necessary embeddedness in historically specific local economies of identity management that include, and perhaps inevitably so, narrative projections about geohistorical « origins » that may - but need not correlate with constructions of racial identities.

Nowhere, perhaps, is this more evident than in the case of Cuba's patently and undisputedly African derived religious traditions : both oral tradition and documentary evidence clearly indicate that by 1857 , Havana had become the scene of the inauguration of the first chapter of a southeastern Nigerian type of secret society entirely composed of socially white men (Palmié 2006). What is more, less than a generation after five Yoruba-speaking Africans, in the 1890s, finally fixed the initiatory mechanisms by which the Ifá-oracle would henceforth be reproduced in the New World, the first white priests of Ifá became active in western Cuba (Brown 2003). By the 1920s, the Ifá-oracle - just like the cult of Changó - had become indigenous to Cuba. But they had done so by transcending some of Cuba's most solidly entrenched social barriers. That dishes with patently 
African-derived names such as « fufú » (mashed plantains, Musa paradisiaca or ñame, Dioscorea alata) are nowadays not only not regarded as emblematically " black » but, on the contrary, perceived as part of the " vianda » complex (a starchy " core » of usually native tubers or plantains that must accompany the similarly inevitable rice and beans) which, ideally, form parts of any truly Cuban meal ${ }^{26}$, is only a less spectacular instance of this particularly Cuban logic of " transracial Africanity » that Fernando Ortiz (1940), by the late 1930s, began to subsume under the label «Africanía ». What he meant was a form of identification crucial to the ideology of « hybrid » New World nationhood that he was trying to elaborate at the time : opposed to the mere fact of being and remaining " African », but instead constituting a moment within an historical dialectic that would eventually transform mere "Cubanidad " into conscious "Cubanía ", "Africanía » represents a deliberate identification with African-derived cultural forms by Cubans of whatever descent or phenotype. It is thus (as Comandante Castro, for reasons of his own, has grown increasingly fond of emphasizing over the years) essentially and necessarily a part of an ideology of national becoming that must transcend race (see Palmié 1998) - and is therefore capable of tolerating all kinds of assertions of "Africanity " in the public sphere, while severely restricting any form of « racial» identity politics ${ }^{27}$.

And in that sense, there is yet another set of New World histories crucial to the making of the amalá con quimbombó Carmen cooked for me in September 2000. I have never been to the house of the cult group in Cienfuegos where Carmen's sister's culinary regime holds sway. But it is not at all counterintuitive to think of the hybrid culinary knowledge underlying this dish as having been transmitted to our days by a succession of priests and cooks not just of African, but European, and quite possibly also Asian descent - or, indeed, various combinations thereof. This is not so because Cuban constructions of race "somehow " allow for degrees of disarticulation between notions of " blackness " and " Africanity " that North Americans find hard to translate into the terms of an ideology of the discrete distribution of racially marked cultural forms among the members of mutually exclusive social groups defined in accordance with seemingly rigid, but in fact historically highly variable notions of African or European descent ${ }^{28}$. They do, and precisely because - for historical reasons - Cubans came to elaborate patterns of social exclusion based in an ideology of all-embracing nationhood, that allows for what Roger Lancaster (1992) calls a characteristically Latin-American form of " racism in the absence of corporate races » (see Palmié 2002). Nevertheless, neither North American types of white racist mobilization and black cultural nationalism, nor Latin American-style « all inclusive ideologies of exclusion » (Stutzman 1981 ; see Martínez Echazábal 1998) are anything but local cultural formations elaborated from - and only seemingly riding above - the historical divergent ways in which projections of « racially " conceived modes of social identification have been harnessed to political agendas that 
are well served by a conflation of nature and culture (Wade 1993). For all representations of the relations between specific cultural forms and the social identities of those who avail themselves of such forms are, of course, themselves cultural constructions - products, in this case, of locally specific, and differentially politicized, forms of the genealogical and historical imagination.

The knowledge required to make proper amalá, recite the verses associated with a particular sign of the ifá-oracle, open up a bank account, or maintain a specific racial identity is, after all, not innate, but socially acquired. And there is nothing particularly mysterious or intriguing about that fact - at least in principle. I, myself, first heard the myth of how Changó's first wife Obá once cooked up one of her ears to make obe for his amalá (Bascom 1992) from the socially white wife of a socially no less white priest of Changó : Ernesto Pichardo - the man who in 1993 won a U.S. Supreme Court case legalizing animal sacrifice for his properly incorporated Church of the Lukumí Babalu Ayé whose beliefs and practices Pichardo consistently qualified as African ${ }^{29}$. That any of this should strike some observers as surprising surely says more about their own culture, and its thorough naturalization of an imputed linkage between ancestry, physique, and cultural repertoire, than about the symbolic universes people like Pichardo, or, for that matter, my friends José Luís and Cármen inhabit ${ }^{30}$.

And here we come to a final issue Sidney Mintz has consistently reminded us of for the past half century : neither " race" nor " origins " are anything but socially and historically contingent constructions. As both the black writer and activist Leroi Jones (Amiri Baraka 1966), and the founder of the Nation of Islam, the honorable Elijah Muhammad (1967) clearly recognized in their own very different ways, eating corn bread, collard greens, ham hocks, or chitterlings, by itself, does not constitute an assertion or rejection of certain identities, subject positions, or visions of collective history. What does, is the symbolic act of situating these same foods within narratives about their significance for patterns of commensal affinity among the oppressed and excluded (as in the case of Jones/Baraka), or about racist conspiracies to destroy the health, vigor, and self-esteem of the members of the lost-found Nation of Islam in the wilderness of North America, in Elijah Muhammad's case. In both instances, the call for sumptuary reform encapsulates prescriptions for historical agency (Comaroff 1985) - envisioned to result in a return to a cuisine rooted in, and authenticated through, the shared historical experience of slavery, as Jones/Baraka argued, and, in the case of the Nation of Islam, in a rejection of precisely that culinary tradition as part and parcel of the "white tricknology " by means of which the continuation of an unwitting complicity of the " so-called Negro " in his own oppression is ensured. Or consider the biting sarcasm with which co-founder of the Black Panther Party Eldridge Cleaver (who neither held sympathies for the Nation of Islam's nor Jones/Baraka's position), at about the same time, castigated the late 1960s African American "emphasis on 
Soul Food» as a «counter-revolutionary black bourgeois ideology » : "You hear a lot of Jazz about Soul Food» he wrote in 1968 (Cleaver 1992, p. 40. Emphasis in the original) :

Take chitterlings : the ghetto blacks eat them from necessity while the black bourgeoisie has turned it into a mocking slogan. Eating chitterlings is like going slumming to them. Now that they have the price of a steak, here they come prattling about Soul Food. The people in the ghetto want steaks. Beef Steaks. I wish I had the power to see to it that the bourgeoisie really did have to make it on Soul Food. ${ }^{31}$

To paraphrase Marx, for Cleaver, the black revolution could draw neither its poetry, nor its cuisine from a past of slavery and oppression, nor could it withdraw into an imaginary culinary community based on invented countercultural traditions. The emphasis here must be on " tradition » rather than « invention » - for it is surely no accident that Ron Maulana Karenga hatched his ideas about Kwaanza at the time of his break with the Black Panther Party. Officially sanctioned by President Clinton in 1996, the festive meals of Kwaanza and its associated African American heritage industry are now, of course, part and parcel of a booming U.S. market in what one might call " diversity goods " (Hernández-Reguant 1999; Domínguez 1994). Yet how even more striking then that food would have served as a common idiom - and by no means an unimportant one - in, and through, which self-consciously black oppositional subjectivities and ways of belonging were delineated and fought over in those heady days when the U.S. Civil Rights legislation had barely been accomplished!

Make no mistake here : « validations or denials [of such discourses on identity or historical subjectivity] through the employment of cultural forms depend upon the symbolic associations - the meaning or significance - of each usage to those who hold positions within a given social system or sub-system " (Mintz 1970, p. 10), not on the real or putative origins, in time and space, of the forms in question. For just as ingesting blanquette de veau or coq au vin does not, by itself, turn people into Frenchmen, eating amalá, ackee and saltfish, mwamba, collard greens, or bean cakes after all, have yet to make a Yoruba, Jamaican, western Central African Bantu-speaker; U.S. African American, or Black Muslim out of anyone on such ground alone. In fact, terms such as « origins » or « identities » are largely meaningless unless they are properly contextualized in historical patterns of interested local deployment - even, and perhaps especially - if such forms become locally available, or at least endowed with accentuated significance for the imagining of culinarily bounded communities, through mass-mediated, and nowadays principally global networks of distribution (such as e.g. the internet).

This holds true in particular for the « Afrocentric " gastrographical revisionism currently underway in the post-aflirmative action United States. There the 
pursuit of culinary « roots » has lately become part of a larger heritage industry catering to consumers economically capacitated to engage in a nutritional identity politics of culinary self-authentication. Following Appadurai (1988), Hernández-Reguant (1999) thus argues that the « rise and increased visibility of a black middle class as a result of the Civil Rights movement and affirmative action policies, as well as the multicultural movement of the late 1980s onward have produced the creation of a specific African-American cuisine ». One could debate, of course, whether the culinary practices in question were « created » or rather belatedly objectified as a culinary and consumptive regimen in the slew of cookbooks and articles devoted to soul food, Kwaanza meals, or culinary PanAfricanism appearing in food and lifestyle magazines since the $1980 \mathrm{~s}^{32}$. Yet it is clear that the proliferation of such culinary discourses is not just symptomatic of the integration of cultural forms marked as « black » into a multicultural spectrum of readily commodifyable forms of « difference ». This trend also bespeaks the transformation of prior modes of racialization in the U.S. public sphere - to the extent that the conspicuous display of cultural practices marked as « African » (or « born from slavery », for that matter) is not only no longer a sign of abjection, but, on the contrary, has become the prerogative of those consumers whose social "blackness » no longer excludes them from aspirations to full market-participation, and so from what some political theorists nowadays call "cultural citizenship " in a self-consciously multicultural nation savoring « diversity » in properly packaged form.

Yet what does it mean to " have » a cuisine of one's own (or, for that matter, a " culture », " history », or even "identity ») ? And why - to extend a question Mintz (1996b) posed à propos the issue of whether « national cuisines » could be said to exist - would any of this necessarily be a good thing ? As Simon Harrison $(1992 ; 1993 ; 1999)$ has argued, the objectification - and monopolistic patrimonialization - of intangible cultural forms (such as the knowledge necessary to perform a divination rite or cook a certain dish) is not just characteristic of post-enlightenment western cultures where Herderian (and similar romantic) notions of deeply rooted national particularity and "genius » were to play a momentous political role after the shocking denouement of the universalisms of the French Revolution. We do, of course, find such political instrumentalizations of notions of "cultural property » all over Melanesia, parts of Native North America, or early colonial Africa where a regular commerce in recipes - and I am using that term advisedly - for cult agencies, objects, and ritual had most likely long antedated the effective colonial moment. Nevertheless, as Richard Handler (1988) was probably first to point out, the regulated exchange of « immaterial possessions » that such scenarios illustrate, was significantly enhanced, and often re-directed, by ideas of " culture », « tradition », " heritage » (or what have you) as goods potentially analogous to western notions of individually or collectively held property that restrict or exclude the consumption, enjoyment or usufruct by 
others on the basis of essentially Lockean theories of property-creation or Hegelian notions of self-realization in a world of objects. Rightful ownership, in that sense, resides with whoever has decided to extricate things from a state of nature, mixed her (or in this case better : their collective) ingenuity with it, and thereby performed an act of - potentially repeatable - production of what Bourdieu (1984) would call cultural capital circulating in a social field conceived of as a market in which actors and groups compete for scarce resources consisting in symbolic markers of distinction.

Again, we might debate the origins and intellectual history of such conceptions. But it should be clear that on a basic level the claims Carmen might have laid on her amalá that evening in el Vedado qua her undisputed African ancestry could - just could ! - be very different from the ones I might launch if I cooked and served that same dish to my wife or friends in Chicago (say, for example, to authenticate my fieldwork experience). But given that recipes - like many other models " of and for " behavior - are, in principle, easily reproducible across all kinds of cultural and social boundaries, would Carmen think that I pirated significant aspects of her historical, cultural, or racial identity or, alternatively, served culturally inauthentic food (as a German cooking Cuban food for what likely would be Americans) ? I think not. But my case rests largely on an instance of friendship, and my limited understanding of the - considerable - differences between Cuba and the U.S. in regards to social investments in the symbolic power of culinary "objects " (including both foods and their recipes) to likewise objectify, render palpable (or palatable, if you will), and potentially appropriable, notionally significant aspects of the collective identities of their original creators and "rightful » consumers. For what is striking in the North American case is that a historically specific, and nowadays evidently market-driven, conjunction between notions of « cultural origins " and corporative understandings of " racial » collectivities has produced an ideology suggesting that such groups not only "possess » clearly delimitable " cultures " or " heritages », but that they ought to maintain « an exclusive association with distinctive sets of symbolic practices [...] and prevent those defined as outsiders from reproducing these markers of identity 》 (Harrison 1999, p. 243).

Let me not equivocate here : Cubans do draw boundaries around what they call « comida criolla » (and basically understand as local homestyle cooking) in juxtaposing such a « national » (or even patriotic - see Dawdy 2002) - cuisine to unmitigatedly foreign foods ${ }^{33}$. But they seem rather unconcerned about its reproduction by non-nationals, and certainly do not routinely invest it with racial meanings. In contrast, a peculiarly North American ideology concerning aspirations to recognition and meritocratic rewards regarded as principally achievable by all members of mutually exclusive, notionally descent-based groups that supposedly possess clearly bounded cultures has led to a culinary identity politics 
where multicultural equal opportunity cooking and eating makes it necessary to regard one's group's culinary knowledge and practices as a heritable, but ultimately scarce, resource ${ }^{34}$. In the case of recent African American culinary writing, this means that guarding such knowledge against de-authentication, « identity theft ", or "culinary colonialism » becomes crucial to maintaining a sense of authentically « black » collective selfhood grounded in the uniquely North American alignment of notions of African cultural origins with ideas about biological « race » that has, in recent years, increasingly begun to take on « Atlantic » if not global dimensions. For while non-black « racial others » might be granted the right to enjoy, but never regard as " theirs ", a cuisine notionally traced to a continental African homeland, the same logic allows for the symbolic repatriation of dishes of oftentimes extremely heterogeneous provenience, but associated with people who would be regarded as black in the U.S., in an " originary » matrix of largely North American ideological origin ${ }^{35}$. The paradoxical outgrowth of this is a kind of culinary " poetics of relation 》 (Glissant 1997) that allows the U.S. African American culinary nationalist to - as Grosvenor (1999, p. x) puts it in an apt turn of phrase - « travel » the "Afro-Atlantic foodways » in search of what, with apologies to Gilroy (1993), one might call a « countercuisine » unified around a conception of blackness increasingly imagined as both biologically based and geo-historially determined.

At this point, however, the very contrast between what I have called an « ackee and saltfish » and an " amalá con quimbombó » model of African American cultural history not only dissolves in the face of a totalizing narrative capable of horizontally assimilating Cuban amalá to Barbadian coo coo, Southern cornbread, or even polenta, while vertically tracing all of them to an essentially African system of roots. Their status as modeling devices itself must now become object of analytical scrutiny. Whatever their specific usefulness in interpreting or deliberating concrete historical or ethnographic data may be, their epistemological status is that of models of a historical reality to which we have, to put it optimistically, only mediate access. What is more, such models - as public discursive productions - are obviously not politically innocent, or epistemologically transparent. Instead, they too are subject to, and expressions of, the kinds of processes White (1973) described as the (perhaps inevitable) narrative moralization of the past in its relation to the present in which " modern " historical forms of knowledge production are arguably rooted, and which, to paraphrase Hobsbawm (1971) endows such models (or better perhaps : the stories spun from them) with social and political functions. Thus we arrive at a point where - and certainly not without regrets - it has become time for me to take leave of my own analytical contrivance, and abandon both ackee and saltfish and amalá con quimbombó as better (or worse) metaphorical devices to capture an « objective » past. That this is so owes to the fact that they never were " just » abstract modeling devices, but 
necessarily (if - perhaps ! - unwittingly) political interventions as well : plotting devices for rooting the present in a past plausible not just on an analytical level, but a moral one as well.

However, to abandon my own culinary metaphorics - as I think I ought now does not mean that I - or anyone else, for that matter - could gain any more privileged access to, let alone escape, what Fernando Ortiz once called the " cooking » of history (Palmié 1998) : a dialectical process of which our own scholarly endeavors cannot but form a part as well, and which - once we become aware of it - can generate what Sidney Mintz (1989) once described as the dizzying "sensation of moving while standing still». As modeling devices, neither ackee and saltfish, nor amalá con quimbombó can realistically be viewed merely as interpretations of the past that would not, by the same token, imply a moral and political vision of what such constructions of history ought to mean for the present ${ }^{36}$. Personally, I would make no bones of preferring the heuristic possibilities opened up by an ackee and saltfish model of African American cultural history over a New Revisionism that rests on syllogisms for which amalá con quimbombó only appears to offer an appropriate analogy. Either way, however, I see little choice but to regard both as mere « recipes » for representing a past the " reality » of which ultimately remains within discourse, rather than beyond it. This is a fact that forms an essential, and not merely an incidental (e.g. due to bad thinking, ideological distortions, improper methodology and so forth) conundrum which we can only acknowledge, but not supercede. If that sounds defeatistic or Pyrrhonic (depending upon one's stake in the debate - see Dianteill 2003), let us remember that none of this absolves us from the pursuit of rigorous scholarship. For what we $c a n$ do, perhaps, boils down to what Sidney Mintz has taught us to do all along : pay close attention to the concrete local structures of opportunity and constraint (including those socially habituated dispositions or ideological regimes enabling their perception), and the larger, perhaps global, structures of power - in both its material and symbolic manifestations - with which they inescapably articulate. For it is under such conditions that we all weigh our behavioral options (including analytical moves), generate and reproduce our cultural worlds, thereby make our histories and cuisines... and cook up stories about both. *

* Manuscrit reçu en mars 2005, accepté pour publication en novembre 2005.

\section{NOTES}

1. I thank John Peel for sharing this gem of contemporary Yoruba culinary wisdom with me. The condiment itself was invented by the Swiss flour merchant Julius Maggi (1846-1912) and first marketed in 1887. The history of its astounding spread throughout Africa and Asia, to my knowledge, still awaits serious study. 
2. My sincere thanks go to Elizabeth Dunn and Elizabeth Ferry for organizing the feast - a panel at the 2002 American Anthropological Association Meetings - at which I first dished out an earlier version of this paper. Subsequently, it has greatly profited from the comments and criticisms I have received from Greg Beckett, Stefania Capone, Elie Goldschmidt, Bobby Hill, Sidney Mintz, Salikoko Mufwene, and Mary Weismantel. Needless to say, all errors and inconsistencies are of my own making.

3. With the outstanding exception of Price (1991) and Dawdy (2002), scholarly treatments of Caribbean foodways and cuisines have been few, far in between, and largely restricted to either brief general overviews such as Parry (1955; 1956), Pereda Valdés (1956), Cassidy (1961, pp. 188-202), Ortiz (1966), Villapoll (1977), Mintz (1987-1988), and Fleury (1993), or culturally relatively « thin » accounts of the diet and nutritional status of slaves compiled from plantation account books and similar sources (e.g. Kiple and King 1981 ; Higman 1984, pp. 204-218). In marked contrast, recent years have seen a virtual explosion of Caribbeana on the cookbook shelf. As Higman (1998) points out in a pioneer contribution modestly qualified as an "hors d'œuvre", this literature, as well as the structures of both local and global demand that appear to drive its production, likewise have yet to see serious study.

4. On which see, for example, Bell (1917), Bailyn (1955), Morison (1961), or the entries for John Carter Brown or Thomas H. Perkins in Freeman Hunt's Lives of American Merchants (Hunt 1969 [1856-1858]).

5. On Bligh's fateful breadfruit adventure see Mackay (1974). As Parry (1956, p. 33) tells us, the first documented ackee slips to arrive in the Caribbean were purchased by Jamaica's first Island Botanist, Dr. Thomas Clarke, allegedly from the captain of a slave ship in 1778. Bligh merely brought Jamaican ackee specimens to Kew Gardens after having finally carried through his breadfruit mission in 1793 without incurring another mutiny. The first systematic description is found in the appendix on the Hortus Eastensis of Bryan Edwards' The History, civil and commercial, of the British colonies in the West Indies (1793). See Rashford (2001).

6. In this sense, the case of ackee (like that of manioc) provides an excellent example in support of Carney's (2001) contention that traditional studies of crop diffusion have tended to severely restrict our understanding of the cultural processes involved in the transfer of cultigens. Just as commercial riziculture in the Americas might well not have taken off successfully had the plant not diffused in conjunction with what she calls an entire African « knowledge system " comprising both agrarian and culinary practices, so is the indigenization of ackee in Jamaica (or of manioc in Africa) as a food crop (as opposed to a mere botanical import) unthinkable in the absence of a parallel institutionalization of systems of toxicological knowledge of African (or, in the case of manioc, ultimately Native American) origin.

7. Curtin's (1969, p. 3) pithy definition of this system is as follows : "A complex economic organism centered on the production in the Americas of tropical staples for consumption in Europe and grown by the labor of Africans ». Hard to imagine, though it is, the Grenada-born calypsionian Slinger Francisco's (The Mighty Sparrow 1984) marvelous ode to Saltfish is unthinkable were it not for the historical reality of the nutritional requirements of the enslaved labor that energized this system - which, of course, is not to say that Sparrow's luxurious double-entendre, or for that matter, the various local use - culinary or symbolic - of salt cod in the Caribbean could be reduced to such political economic considerations. In fact, this is precisely the point.

8. As the following passage makes unmistakably clear, Mintz and Price were not at all discounting the role of originally African cultural forms in such processes. What they were concerned with was the kind of "instant » history derived from mere formal comparison - a problem M. G. Smith (1965, pp. 24-37) had raised as early as 1955 : " It should no longer seem sufficient ", Mintz and Price (1992, p. 41) write : « to maintain that Haiti's twin cult, the worship of Shango (Xango) in Trinidad or Bahia, or the use of oracles in Suriname are simply examples of Africa transplanted, or even of specific ethnic continuities of culture. Our task must rather be to delineate the processes by which those cultural materials that were retained could contribute to the institution-building the slaves undertook to inform their condition with coherence, meaning, and some measure of autonomy ". 
9. Of course, this may not have been the only issue involved : since the late 1950 s, the Caribbean region had also begun to play a new role in discussions about the anthropological study of « complex societies ", and the forms of domination characteristic of agro-industrial production sites on the periphery of the global capitalist system. Yet perhaps precisely because Caribbean and African American anthropology became overtly politicized in the U.S. in the course of the 1960s, by the time Mintz and Price first launched their intervention in print (1976), the disciplinary sub-field to which it most directly spoke had arguably, and in some sense purposively, " missed the boat " of the hermeneutic and symbolic approaches dominating « high prestige » debate in the late 1960s, opting instead for a political-economic historicism or sociological empiricism, then hardly in the forefront of American anthropologists' theoretical concerns. And it was soon to become associated with precisely those " foundationalist » epistemologies, localizing strategies, and grands récits against which a new generation of anthropologists influenced by feminist theory, French poststructuralism, literary criticism, and postcolonial theory was beginning to rail. On the latter issue see e.g. Mintz' (1989) own reflections on ethnographic subjectivity, the exchange between Taussig (1989) and Mintz and Wolf (1989), as well as Robert Brightman's (1995) thoughtful critique of contemporary anthropological vanguardism. It is true, however, that even before Taussig complained about the conspicuous absence of «epistemic murk $»$ in Mintz and Wolf's versions of marxism, an increasing policy orientation - e.g. in the debate about M. G. Smith's plural society thesis and R. T. Smith's Parsonian value integration model (see Austin 1983 for a well-reasoned critique of both positions) - steered Caribbean anthropology away from questions then at the forefront of the discipline as a whole, and may have lastingly contributed to what Carnegie (1992) diagnosed as a decline of ethnographically oriented social science research in the region. It may be in light of this that one needs to understand the somewhat vindicationist tone in which Slocum and Thomas (2003) have recently re-evaluated the contribution of Caribbean anthropology to the concerns of the discipline as a whole.

10. That it was published in the same year as Alex Haley's wildly popular, but academically shunned if not excoriated "saga " Roots (on which see Moore 1995) could not have helped matters either.

11. By and large, the current anthropological vogue for analytical metaphors derived from Caribbean ethnographic scenarios is datable to Hannerz (1987) and Clifford (1988). Mintz (1996b), Khan (2001), and Trouillot (2002) provide well-taken critiques of metonymical extension of concepts originating in Caribbean ethnography to the analysis of a world allegedly « in creolization ".

12. In the U.S., this curious oscillation between origin-centered "Africanist " and contextcentered "Americanist " emphases in the historical reconstruction of the emergence of African American cultures goes back (at least) to the debates, beginning in the 1930s, between Herskovits and his life-long opponent, the black American sociologist E. Franklin Frazier. On the intellectual and political background of these debates - which not only coincided with the emergence of the U.S. Civil Rights Movement, but articulated with it in complex ways - see Szwed (1974), Jackson (1986), Williams (1996), and Baker (1998). Perhaps not surprisingly, similar analytical polarities are virtually absent in scholarship originating in the Caribbean, and have only recently emerged in Brazil. Whether or not this may relate to an increasing influence of North American conceptualizations of "race " on local scholarship in the latter country - as Bourdieu and Wacquant (1999) contended in a hotly debated polemic against what they perceive as imperialist tendencies in U.S. based scholarship - is a question well beyond the scope of this essay.

13. A point that Price (2001, p. 44) himself has readily conceded.

14. See, for example, Asiwaju (1976), Mudimbe (1988), Peel (1990, 2000), Amselle (1993, 1998), MacGaffey (1995), Caron (1997), Morgan (1997), Moore (1998), or Northup (2000).

15. The term refers to a formally institutionalized Afro-Cuban religious cult group. Today's Afro-Cuban " casas de santo " have often been traced to the longstanding Ibero-American institution of the " cabildo de nación "-i.e. voluntary associations of ethnically alien individuals (in this case of African origin) subordinated to Spanish rule (Ortiz 1921 ; see also Brown 1993, 2003 ; Palmié 1993). 
16. Lluriá de O'Higgins (1994, p. 199 sq.) features a fairly up-scale (one suspects : exile-enhanced) version of the dish served with plantain dumplings.

17. Moreover, given the then current exchange rate of 22 Cuban pesos to the U.S. dollar, a quart of vegetable oil sold at prices ranging between U.S.\$ 2.25 to 2.75 in Havana's government-owned « tiendas de recaudación de devisas » (TRD - more popularly known as " chopins ») still represented a considerable investment. See Pérez López (1995, p. 57), Segre, Coyula and Scarpaci (1997, p. 229 sq.) and LeoGrande and Thomas (2002, p. 352) for the development of disparities in purchasing power among different income groups in the national currency and dollarized market sectors.

18. Surprisingly, the one monograph/cookbook devoted to Afro-Cuban ritual cuisine (Bolivar Aróstegui and González Díaz de Villegas 1993) does not mention the dish, but instead gives « arroz con quimbombó » as a sacrificial food for the deity Babalu Ayé. In contrast, a sacrificial cookbook published by the American Yoruba Movement's Theological Archministry (Edwards and Mason 1981, p. $58 \mathrm{sq}$.), features recipes for amalá with an okra stew as sacrificial foods for Changó - but « deCubanizes » the resulting dish by calling it «ọbẹ ila » (see Palmié 1995; Clarke 2004).

19. Villapoll (1977) notes an analogy between Hispano-Caribbean culinary conceptions of " sofrito » (a multi-purpose base for savory food preparations consisting of onions, garlic, peppers and tomatoes) and the Yoruba concept of ata (seasoning, literally, pepper), but concedes their very different role in composing dishes - the first representing a flavoring base on which a variety of dishes are elaborated, the second representing a seasoning added at the end of the cooking process. Interestingly, in the case of Cármen's amalá, the two conceptions converged upon a « sofrito " based sauce added to a corn-mush.

20. On the former question see Zeven and Zhukovsky $(1975$, p. 68). As regards the latter, Alpern (1992, p. 31) adduces intriguing, though hardly conclusive, linguistic and ethnographic evidence suggesting that the Portuguese may have brought okra from the region of present-day Ghana to the Bight of Benin. If so - and pace Chambers (1997, p. 85) - the possible Twi etymology nkuruma < okra might indicate that the Igbo word okoro is, in fact, derived from an English phonetic corruption of a Twi term and may have replaced local designations derivative of the Portuguese " quiabo " in the southeastern Bight of Benin (which are documentable to this day) only at a fairly late date in the transatlantic slave trade! See note 23 infra.

21. Following Thornton in pushing the moment of " creolization » back towards « pre-Atlantic » African contexts has recently emerged as a strategy to mediate the two positions (see Berlin 1996 ; Heywood 2002). Whether this solves any of the theoretical problems involved, or merely allows its proponents to eat their African cake and creolize it, too, remains to be seen.

22. For the history of maize and manioc in Africa see Miracle (1966), Jones (1959) and Alpern (1992).

23. The word itself presents yet another puzzle. Already in 1875, Pichardo (1985, p. $511 s q$.) gave a botanical identification of "quimbombó " as Hibiscus esculentus or Abelmoschus esculentus, and ascribed an African origin to the term. As Ortiz (1924, pp. 400, 403) surmised (albeit on the basis of dubitable Angolan evidence) its geographical origins lay in western Central Africa, and «quimbombó » represents a Cuban corruption of « quin'gombo ». This is born out in Da Silva Maia (1961, p. 519) who gives " kingombo » as the Kimbundu term for okra, and " mbundu kia nxi » (note the Portuguese spelling) as the Kikongo equivalent (in contemporary Kikongo the latter phrase, in fact, means « fruit of the land/earth » as opposed to imported food, or tree crops). More surprising, perhaps, is the fact that Cabrera $(1983$, p. $532 ; 1984$, p. 134) would note that the term « quimbombó » is not used as a referent to Hibiscus esculentus in the ritual language of Cuba's reglas de congo where it is variously referred to as " balango ", " bañe », " gondei » (" goudei »), " dimba », " ndimba » or " ngungo ». Díaz Fabelo (1998, p. 59) augments that list with the following terms culled from the ritual lexicon of the Cuban "reglas de congo »: "molondrón » (in fact a common term for okra in Puerto Rico), " nguenso », « dongo dongo » and " nguindo ». As Salikoko Mufwene (personal communication) tells me, we ought to reckon with the interference of West African languages in lexical patterns Cubans now regard as pertaining to " congo » ritual registers. 
24. On the historical patterning of Cuba's slave intake see Bergad et al. (1995) and Tornero Tinajero (1996). Morton-IVilliams (1964), Akinjogbin (1967) and Law (1977) still represent the best introductions to the political dynamics in the Bight of Benin that, by the early 19th century, came to integrate the various Yoruba-speaking polities of southwestern Nigeria into the South Atlantic System as exporters of slaves to the last two major slave-importing regions of the New World-Cuba and northeastern Brazil.

25. Of course, to speak of a " Central African sauce » is to potentially open up another Pandora's box of conceptual and terminological confusions. Foodways in the lower Zaire are attested to in the copious Portuguese and Italian missionary literature since the middle of the 16th century (Balandier 1968, pp. 156-163). Yet the single one comparative study (Obenga 1992) is not only rather superficial, but fails to mention okra as a culinarily significant plant - although Vansina's historical lexicostatistics $(1990$, p. 84$)$ trace its use to a comparatively ancient linguistic stratum. Milheiros $(1967$, p. 25$)$ gives a 20 th century Angolan recipe which combines okra with peanuts (ginguba) and hot (New World) peppers (gindungo) - the latter of which (i.e. *ndongo) Vansina (1990, p. 290) identifies as « proto western Bantu » in form, though, of course, not substance. Chances are good that the okra sauces that enslaved Yoruba-speakers arriving in Cuba in the early 19th century might have been offered by already resident Central African and creole slaves would have born names phonetically close to mwamba, moamba, or muamba - neither of which survive in documented or contemporary Cuban speech. Yet even if so, whether such mwamba would have been okra-based is open to question - not the least in light of the fact that okra figures prominently among foods tabooed for practitioners of western Central African derived Afro-Cuban religious traditions who, as Cabrera (1983, p. $532 \mathrm{sq}$.) claims, fear that the slipperiness of ingested okra-preparations will render their ritual works (" trabajos ») equally " slippery ", hence incapable of "sticking " to their intended objects or victims. Whether that may be a latter-day " Kongoism » or not I leave to the New Revisionists to decide.

26. See Dawdy (2002) who makes a good case not only for the comparatively early emergence of this - particularly Cuban - core/fringe pattern, but for its association with Cuban nationalist ideologies, evident as early as the mid-19th century.

27. An indicative case is the Asociación Cultural Yoruba which is led by a group of socially white babalaos, and conspicuously housed on Habana Vieja's Paseo del Prado in a beautifully restored colonial palace across the Parque de la Fraternidad Panamericana. Although its current director Antonio Castañeda claims that the building was renovated with funds donated by religious clients and supporters from abroad, it is clear that the choice of site and allocation of materials, permits, etc, could only have been realized through state patronage. A somewhat different, but equally instructive case is that of the Cuban state's reluctant co-optation of patently U.S. African American-inspired musical styles known as « Rap Cubano » (Fernandes 2003).

28. A good case in point is the 2004 U.S. Democratic presidential candidate John Kerry's Mozambique-born, socially white wife Teresa Heinz Kerry's reported self-identification as "African American » (Swarns 2004). Whether one regards such a statement as meaningful, nonsensical, or even offensive depends upon whether one chooses to assign "racial " significance to predications of "Africanity ». But it bears pointing out that the seeming paradoxicality of Heinz Kerry's claim tends to diminish or even vanish once one leaves the operational orbit of a peculiarly North American logic of race which, for historical reasons, makes it difficult to think of "Africanity " in the absence of socially black people (Palmié 2002).

29. On which see Palmié (1996). Perhaps not incidentally, Bascom (1992) refrained from specifying the contextual racial identity of the New World informants from whom he collected myth's about Obá's ear in Changó's amalá.

30. Cubans white or black are thus apt to consciously and conspicuously engage in cultural practices that they themselves understand as "African ", while still - and sometimes in the same situation (say, while eating amalá or discussing divination signs) - making highly stereotypical remarks about the worthlessness of people " de bajo nivel de cultura " ( " of a low level of culture ") who often happen to be of darker skin color than they themselves. A particularly striking example of this logic 
was evident in South Florida in the mid-1980s, when an unprecedentedly large contingent of darkskinned individuals among the 125,000 Cubans arriving in the course of the so-called Mariel Exodus prompted anxious responses not only from Miami's established Cuban community fearing for its " white model minority status » (Palmié 1989), but elicited hostile reactions among Miami's practitioners of Afro-Cuban religions as well. When I was doing fieldwork there in 1985, the rancor (driven in part by claims of some new arrivals that their practices represented a more authentically Cuban tradition) between resident santeros and black newcomers (many of whom bitterly complained of receiving a cold welcome from Miami's santería community) was still very much alive.

31. For the more recent integration of elements of " soul food » into the Halal cuisine of African American Sunni Muslims and its significance for - what possibly may be thought of as - a new oppositional politics of consumption see Rouse and Hoskins (2004).

32. As Poe (1999) argues on the basis of good evidence, the transformation of black southern cooking into a self-consciously "debatable " signifier of African-American identity (positive or negative) occurred in the process of the establishment of a segregated restaurant industry in those northern urban centers that became targets of the so-called " Great Migration " of African Americans from the rural South to the industrial North in the second and third decade of the 20th century.

33. Such as, for example, French, Italian, Russian, Polish, or Vietnamese cuisine, which was served in restaurants (prior to the beginning of the "special period » in 1991), but probably rarely - if ever cooked at home. To my knowledge, "la comida china " - i.e. the (heavily Cubanized) cuisine of the descendants of 19th century Chinese indentured laborers is the only instance of an " ethmic cuisine " recognized on the island. Although the development of collective representations of a " comida china " on the island must have occurred long ago, it is, perhaps, not incidental that Cubans of Chinese descent are also the only group allowed to maintain overtly descent-based associations in revolutionary Cuba.

34. Here one wonders to what extent the amazingly well-stocked cookbook shelves in Paris' L'Harmattan bookstore might generate a similar impression. Might self-identified Martiniquais cookbook authors worry about a creeping de-authentification or alienation of their culinary legacy under the impact of French cuisine and consumerism in a manner comparable to the ways in which U.S. African American cookbook writers do (or Cubans, for that matter, don't) ? Unprepared as I am to give an answer, I suspect it might be revealing.

35. See Spivey (1999), Williams-Fortson (2001), Harris (2001), Heldke (2001). The logic - and limits - of such conceptions are vividly exemplified in Diane M. Spivey's The peppers, cracklings, and knots of wool cookbook (1999). In this fascinating monograph that doubles (or triples !) as cookbook and gastropolitical manifesto, she self-consciously but cogently argues from a strong position of African American culinary nationalism that since hominization is considered to have first occurred in Africa, the transition from mere hominid feeding patterns to the conscious culinary techniques and gustatory habits of homo sapiens would have occurred there as well. Such an argument, of course, would be entirely in accordance with the model Claude Lévi-Strauss (1966) erected - during a now by-gone era of anthropological confidence in the transparency of linguistic category-formation - upon the possibly universal human distinctions between the raw, cooked, and rotten, that may well mark the crucial step from feeding to eating, or in other words, from nature to culture. This, however, is not the course Spivey steers by. Instead, what she is after is a comprehensive but historically specific - rather than universalizing - theory of the primacy of African culinary knowledge in the making of human foodways, from ancient East Africa to India, China, and those "national » cuisines of the " modern West » that have deliberately forgotten or repressed the African input crucial to their own historical emergence. In an intriguing, and surely deliberate move, she thus replicates Melville Herskovits' (1941) strategy of explicating what he called " The Myth of the Negro Past » before proceeding to demolish it. Spivey's " myth » (as culled from contemporary food-writing) has three components :

- No food products were indigenous to Africa, thereby precluding Africans from being capable of developing any sort of cuisine prior to European intervention, and

- Africans came into contact with ninety-nine percent of the foods they consumed only as a result of the slave trade, and 
- African culinary traditions vary from country to country and have absolutely nothing in common (Spivey 1999, p. 2 sq.).

If Herskovits drew the conclusion : "The Negro is thus a man without a past » from a similar list of prejudiced propositions, Spivey's implied rather than stated conclusion appears to be that « Africans have no culinary past » - a myth she sets out to debunk. To what extent her global recovery of culinary "Africanisms » in virtually all human cuisines ultimately explodes any specific notion of Africanity - and so, in effect, leads Herskovits and the " New Revisionists » ad absurdum - is a subject that I can not adequately deal with in the space allotted here. Let me just add that the very idea of Africa as a point of reference for its diaspora - as W. E. B. DuBois $(1946$, p. 7) pointed out long ago - « stems naturally from the West Indies and the United States ").

36. Nor is their status as mere intellectual interventions to be taken for granted. It has become a commonplace regret among anthropologists that the saturation of western public discourse with notions of " culture » that we ourselves have begun to doubt leaves us with a vocabulary contaminated by tendentious everyday meanings. That this should come as a surprise to any of us, surely belies another instance where anthropology has been "caught napping" (Mintz 1996a, p. 303). For a trenchant critique of such laments see Strathern (1995).

\section{REFERENCES}

\section{ABu Lughod Lila}

1989 "Zones of theory in the anthropology of the Arab world ", Annual Review of Anthropology, 18, pp. 267-306.

AKINJogbin Isaac Adeagbo

1967 Dahomey and its neighbors, 1789-1818, Cambridge University Press, Cambridge.

\section{ALPERn Stanley B.}

1992 "The European introduction of crops into West Africa in precolonial times ", History in Africa, 19, pp. 13-43.

AmSELLE Jean-Loup

1993 "Anthropology and historicity ", History and Theory Beiheft, 32, pp. 12-31.

1998 Mestizo logics : anthropology of identity in Africa and elsewhere, Stanford University Press, Stanford.

ApPaDurai Arjun

1988 "How to make a national cuisine : cookbooks in contemporary India ", Comparative Studies in Society and History, 30, pp. 3-24.

\section{Asante Molefi Kete}

1987 The Afrocentric idea, Temple University Press, Philadelphia.

Asıwaju Anthony Ijaola

1976 «Political motivations and oral historical traditions in Africa : the case of Yoruba crowns, 1900-1960 », Africa, 46, pp. 113-127.

Austin Diane J.

1983 "Culture and ideology in the English-speaking Caribbean : a view from Jamaica ", American Ethnologist, 10, pp. 223-240. 
BAILYN Bernard

1955 The New England merchants in the seventeenth century, Harvard University Press, Cambridge.

BAKER Lee D.

1998 From savage to negro: anthropology and the construction of race, 1896-1954, University of California Press, Berkeley.

\section{BALANDIER Georges}

1968 Daily life in the kingdom of Kongo from the sixteenth to the eighteenth century, Pantheon, New York.

BAscom William

1951a "Yoruba food ", Africa, 21, pp. 41-53.

1951 b « Yoruba cooking », Africa, 21, pp. 125-137.

1992 African folktales in the New World, Indiana University Press, Bloomington.

BeLl Herbert C.

1917 "The West India trade before the American Revolution », American Historical Review, 22, pp. 272-287.

Bergad Laird, Fe Iglesias García and María del Carmen Barcía

1995 The Cuban slave market, 1790-1880, Cambridge University Press, Cambridge.

BERLIN Ira

1996 "From creole to African : Atlantic creoles and the origins of AfricanAmerican society in Mainland North America ", William and Mary Quarterly, 53, pp. 251-288.

BerLIN Ira and Philip D. Morgan, eds

1991 The slaves' economy, Frank Cass, London.

Bolívar Aróstegui Natalia and Carmen GonzÁlez Díaz de Villegas

1993 Mitos y leyendas de la comida afrocubana, Editorial Ciencias Sociales, La Habana.

BOURDiEu Pierre

1984 Distinction, Routledge, London.

BOURDiEu Pierre and Loïc WACQANT

1999 "The cunning of imperial reason », Theory, Culture and Society, 16, pp. 4168.

BRIGHTMAN Robert

1995 "Forget culture: replacement, transcendence, relexification », Cultural Anthropology, 10, pp. 509-546.

Brown David H.

1993 "Thrones of the Orichas : Afro-Cuban altars in New Jersey, New York, and Havana ", African Arts, 26, pp. 44-59, pp. 85-87.

2003 Santeria enthroned: art, ritual, and innovation in an Afro-Cuban religion, University of Chicago Press, Chicago. 
CABrera Lydia

1983 El Monte, Ediciones Universal, Miami, coll. «Chicherekú en el exilio » [1954].

1984 Vocabulario congo (el bantu que se habla en Cuba), Ediciones Universal, Miami, coll. " Chicherekú en el exilio ».

CARNEGIE Charles

1992 "The fate of ethnography : native social science in the English-speaking Caribbean ", New West Indian Guide, 66, pp. 5-26.

CARNEY Judith A.

2001 Black rice : the African origins of rice cultivation in the Americas, Harvard University Press, Cambridge.

CARON Peter

1997 " "Of a nation which the others do not understand": Bambara slaves and African ethnicity in Colonial Louisiana, 1718-60 ", Slavery and Abolition, 18 , pp. 98-121.

CAssidy Frederic G.

1961 Jamaica talk, MacMillan, London.

Chambers Douglas B.

1997 "My own nation" : Igbo exiles in the diaspora ", Slavery and Abolition, 18, pp. 72-97.

Clarke Kamari M.

2004 Mapping Yorùbá networks, Duke University Press, Durham.

Cleaver Eldridge

1992 Soul on ice, Laurel-Dell, New York [1968].

Clifford James

1988 The predicament of culture, Harvard University Press, Cambridge.

ComarofF Jean

1985 Body of power, spirit of resistance, University of Chicago Press, Chicago.

Curtin Philip D.

1955 Two Jamaicas : the role of ideas in a tropical colony, 1830-1865, Harvard University Press, Cambridge.

1969 The Atlantic slave trade : a census, University of Wisconsin Press, Madison.

Da Silva Maia Antonio

1961 Diccionário complementar Português-Kimbundu-Kikongo, Tipografia das Missōes, Luanda.

DAwDY Shannon Lee

2002 «La comida mambisa : food, farming, and Cuban identity, 1839-1999 », New West Indian Guide, 76, pp. 47-80.

DiANTEILl Erwan

2003 "Review of Stephan Palmié Wizards and scientists », Annales, Histoire, Sciences Sociales, 58, pp. 404-407. 
DíAz FABelo Teodoro

1998 Diccionario de la lengua congo residual en Cuba, Casa del Caribe, Santiago de Cuba.

\section{Domínguez Virginia}

1994 "A taste for the "other" : intellectual complicity in racializing practices ", Current Anthropology, 34, pp. 333-348.

Du Bors William Edward Burghandt

1946 The world and Africa, Viking Press, New York.

EDWARDS Bryan

1793 The history, civil and commercial, of the British colonies in the West Indies, John Stockdale, London.

EDWARds Gary and John Mason

1981 Onje Fun Orisa (food for the gods), Yoruba Theological Archministry, New York.

Eltis David, Stephen D. Behrendt, David Richardoson and Herbert S. Klein, eds

1999 The Transatlantic slave trade : a database on CD-ROM, Cambridge University Press, Cambridge.

FERNANDES Sujatha

2003 " Fear of a black nation : local rappers, transnational crossings, and state power in contemporary Cuba ", Anthropological Quarterly, 76, pp. 575-608.

Fleury Marie

1993 «Food plants and cultural identity : the Boni in French Guiana and African memories ", in Claude Marcel Hladik, Annette Hladik, Olga F. Linares, Helene Pagezy, Alison Semple and Malcolm Hadley, eds, Tropical forest people and food, UNESCO, Paris, pp. 643-650.

FORTES Meyer and Sonia L. FORTES

1936 "Food in the domestic economy of the Tallensi », Africa, 9, pp. 237-276.

Francisco Slinger (The Mighty Sparrow)

1984 "Saltfish ", Party Classics 4: Survival, B.L.S. Records, Frederiksted, St. Croix U.S. VI.

Gilroy Paul

1993 The black Atlantic, Harvard University Press, Cambridge.

Glissant Edouard

1997 Poetics of relation, University of Michigan Press, Ann Arbor.

Gomez Michael

1998 Exchanging our country marks : the transformation of African identities in the Colonial and Ante-Bellum South, University of North Carolina Press, Chapel Hill.

GooDy Jack

1982 Cooking, cuisine, and class, Cambridge University Press, Cambridge. 
Grosvenor Vertamae

1999 Vertamae cooks again : more recipes from the America' family kitchen, Bay Books, San Francisco.

\section{Gutman Herbert}

1976 The black family in slavery and freedom, 1750-1925, Vintage, New York.

HaLL Gwendolyn Midlo

1992 Africans in colonial Louisiana : the development of Afro-Creole culture in the eighteenth century, Louisiana State University Press, Baton Rouge.

1997 "Review of Stephan Palmié, ed., Slave cultures and the cultures of slavery ", American Historical Review, 102, pp. 782-783.

\section{HANDLER Richard}

1988 Nationalism and the politics of culture in Quebec, University of Wisconsin Press, Madison.

HANNERZ UIf

1987 "The world in creolization ", Africa, 67, pp. 546-559.

HARris Jessica B.

2001 "Same boat, different stops : an African Atlantic culinary journey ", in Sheila S. Walker, ed., African roots/American cultures, Rowman and Littlefield, Lanham, pp. 169-182.

HARrison Simon

1992 "Ritual as intellectual property », Man, 27, pp. 225-244.

1993 "The commerce of cultures in Melanesia », Man, 28, pp. 139-158.

1999 «Identity as a scarce resource », Social Anthropology, 7, pp. 239-251.

HELdKe Lisa

2001 "Let's cook Thai : recipes for colonialism », in Sherrie A. Innes, ed., Pilaf, pozole, and Pad Thai, University of Massachussetts Press, Amherst, pp. 175198.

Hernández-Reguant Ariana

1999 "Kwaanza and the U.S. ethnic mosaic », in Jean Muteba Rahier, ed., Representations of blackness and the performance of identities, Bergin and Garvey, Westport, pp. 101-122.

Herskovits Melville J.

1941 The myth of the negro past, Harper, New York.

1966 The New World negro, Indiana University Press, Bloomington.

Heywood Linda

2002 «Portuguese into Africa : the eighteenth-century Central African background to Atlantic creole cultures ", in Linda Heywood, ed., Central Africans and cultural transformations in the American diaspora, Cambridge University Press, Cambridge, pp. 91-113.

Higman Barry W.

1984 Slave populations of the British Caribbean, 1807-1834, Johns Hopkins University Press, Baltimore. 
1998 «Cookbooks and Caribbean cultural identity: an English language hors d'œuvre ", New West Indian Guide, 72, pp. 77-95.

НовSвашм Eric

1971 "The social functions of the past : some questions », Past and Present, 55, pp. 3-17.

Howe Stephen

1998 Afrocentrism : mythical pasts and imagined homes, Verso, London.

Hunt Freeman

1969 Lives of American merchants, Augustus M. Kelley, New York [1856-1858].

INNIS Harold A.

1940 The cod fisheries : the history of an international economy, Yale University Press, New Haven.

JACKSON Walter

1986 "Melville J. Herskovits and the search for Afro-American culture », in George Stocking, Jr., ed., Malinowski, Rivers, Benedict, and others : essays on culture and personality, University of Wisconsin Press, Madison, pp. 95126, coll. « History of Anthropology » 4.

Jones Leroi (Amiri BARAKA)

1966 "Soul food», in Leroi Jones (Amiri Baraka), Home : social essays, William Morrow, New York.

JONES William O.

1959 Manioc in Africa, Stanford University Press, Stanford.

KHan Aisha

2001 "Journey to the center of the earth : the Caribbean as master symbol ", Cultural Anthropology, 16, pp. 271-302.

Kiple Kenneth F. and Virginia Himmelsteib King

1981 Another dimension to the African diaspora : diet, disease and racism, Cambridge University Press, Cambridge.

KuLiKoff Alan

1986 Tobacco and slaves, University of North Carolina Press, Chapel Hill.

KURLANSKY Mark

1997 Cod : a biography of the fish that changed the world, Penguin, New York.

LANCASTER Roger

1992 Life is hard: machismo, danger, and the intimacy of power in Nicaragua, University of California Press, Berkeley.

LAw Robin

1977 The Oyo empire, c. 1600-1836, Clarendon Press, Oxford.

LeoGrande William M. and Julie M. Thomas

2002 "Cuba's quest for economic independence », Journal of Latin American Studies, 34, pp. 325-363. 


\section{Lévi-Strauss Claude}

1966 "The culinary triangle ", Partisan Review, 33, pp. 586-595.

Lluriá DE O’Higgins María Josefa

1996 A taste of old Cuba, Harper Collins, New York.

Lovejoy Paul E.

1997 "The African diaspora : revisionist interpretations of ethnicity, culture, and religion under slavery ", Studies in the World History of Slavery, Abolition, and Emancipation, 2, pp. 1-24.

2000 "Identifying enslaved Africans in the African diaspora », in Paul E. Lovejoy, ed., Identity in the shadow of slavery, Continuum, London, pp. 1-29.

\section{MACGAFFEY Wyatt}

1995 "Kongo identity, 1483-1993 », South Atlantic Quarterly, 94, pp. 1025-1037.

Mackay David

1974 "Banks, Bligh, and breadfruit », New Zealand Journal of History, 8, pp. 6177.

Martínez EchazÁBal Lourdes

1998 "Mestizaje and the discourse of national/cultural identity in Latin America, 1845-1959 ", Latin American Research Review, 25, pp. 21-42.

MCGLynn Frank and Seymour DRESCHER, eds

1992 The meaning of freedom, University of Pittsburgh Press, Pittsburgh.

Milheiros Mário

1967 Notas de etnografia angolana, Instituto de Investigaçào Científica de Angola, Luanda.

Mintz Sidney W.

1966 "Towards an Afro-American history », Cahiers d'Histoire Mondiale, 8, pp. 317-331.

1970 "Foreword", in Norman E. Whitten and John F. Szwed, eds, AfroAmerican anthropology, Free Press, New York, pp. 1-16.

1974 Caribbean transformations, Columbia University Press, New York.

$1985 \quad$ Sweetness and power, Penguin, New York.

1987-1988 "Food origins and syntheses in Caribbean history », Journal of Gastronomy, 3, pp. 35-43.

1989 "The sensation of moving, while standing still », American Ethnologist, 16, pp. 786-796.

1995 "Slave life on Caribbean sugar plantations : some unanswered questions », in Stephan Palmié, ed., Slave cultures and the cultures of slavery, University of Tennessee Press, Knoxville, pp. 12-22.

1996a "Enduring substances, trying theories: the Caribbean region as oikoumene », Journal of the Royal Anthropological Institute, 2, pp. 289-311.

1996b Tasting food, tasting freedom, Beacon Press, Boston.

MinTz Sidney W. and Richard Prick

1992 The birth of African American culture, Beacon Press, Boston. 
Mintz Sidney W. and Eric WolF

1989 "Reply to Michael Taussig », Critique of Anthropology, 9, pp. 25-31.

Miracle Marvin P.

1966 Maize in tropical Africa, University of Wisconsin Press, Madison.

Moore David Chioni

1995 "Routes : Alex Haley's Roots and the Rhetoric of Genealogy ", Transition, 64, pp. 4-21.

1998 "African philosophy vs. philosophy of Africa : continental identities and travelling names for self ", Diaspora, 7, pp. 321-350.

Moreno Fraginals Manuel

1986 El ingenio, Editorial Ciencias Sociales, La Habana.

Morgan Philip D.

1997 "The cultural implications of the Atlantic slave trade : African regional origins, American destinations and New World developments ", Slavery and Abolition, 18, pp. 122-145.

Morison Samuel E.

1961 The maritime history of Massachussetts, Houghton Mifflin, Boston [1921].

MORTON-WiLliams Peter

1964 "The Oyo Yoruba and the Atlantic trade, 1670-1830", Journal of the Historical Society of Nigeria, 3, pp. 25-46.

Moses Wilson Jeremiah

1998 Afrotopia : the roots of African American popular history, Cambridge University Press, Cambridge.

Mudimbe Valentin Yves

1988 The invention of Africa: gnosis, philosophy, and the order of knowledge, Indiana University Press, Bloomington.

MuHAmmad Elijah

1967 How to eat to live, Messenger Elijah Muhammad Propagation Society, Atlanta.

NoRTHUP David

2000 "Igbo and myth Igbo: culture and ethnicity in the Atlantic world, 16001850 ", Slavery and Abolition, 21, pp. 1-20.

OBEnga Théofile

1992 "Tradiciones y costumbres alimenticias kongo en el siglo XVII : estructuras del sabor ", América Negra, 3, pp. 71-88.

Ortiz Fernando

1921 "Los cabildos afrocubanos », Revista Bimestre Cubana, 16, pp. 5-39.

1924 Glosario de afronegrismos, Librería Cervantes, La Habana.

1940 "Los factores humanos de la cubanidad ", Revista Bimestre Cubana, 45, pp. 5-30. 
1966 «La cocina afro-cubana », Casa de las Américas, 6, pp. 63-69.

1995 Cuban counterpoint, Duke University Press, Durham [1947].

PALmí́ Stephan

1989 «Spics or spades? Racial classification and ethnic conflict in Miami», Amerika-Studien/American Studies, 34, pp. 211-221.

1993 «Ethnogenetic processes and cultural transfer in Caribbean slave population ", in Wolfgang Binder, ed., Slavery in the Americas, Königshausen und Neumann, Würzburg, pp. 337-363.

1995 "Against syncretism : africanizing and cubanizing discourses in North American òrìsà-worship ", in Richard Fardon, ed., Counterworks : managing the diversity of culture, Routledge, London, pp. 73-104.

1996 "Which center, whose margin? Notes towards an archaeology of U.S. Supreme Court case 91-948, 1993 », in Olivia Harris, ed., Inside and outside the law, Routledge, London, pp. 184-209.

1998 "Fernando Ortiz and the cooking of history ", Iberoamerikanisches Archiv, 24 , pp. $353-373$.

2002 "The color of the gods : notes on a question better left unasked ", in Berndt Ostendorf, ed., Transnational America, C. Winter, Heidelberg, pp. 163-175.

2006 "The view from Itía Ororó Kande », Social Anthropology, 14 (1) [forthcoming].

PARRY John H.

1955 «Plantation and provision ground », Revista de Historia, 39, pp. 1-20.

1956 "Salt fish and ackee », Caribbean Quarterly, 2 (4), pp. 29-35.

Peel John David Yeadon

1990 "The pastor and the babalawo : the interaction of religions in 19th century Yorubaland ", Africa, 60, pp. 338-369.

2000 Religious encounter and the making of the Yoruba, Indiana University Press, Bloomington.

\section{Pereda Valdés Ildefonso}

1956 "Culinaria afroamericana », in Miscelánea de estudios dedicados a Fernando Ortiz, Sociedad Económica de Amigos del País, La Habana.

Pérez López Jorge F.

1995 Cuba's second economy, Transaction Publishers, New Brunswick.

Pichardo Esteban

1985 Diccionario provincial casi-razonado de voces y frases cubanas, Ciencias Sociales, La Habana.

PoE Tracy N.

1999 " The origins of soul food in black urban identity : Chicago, 1915-1947 », American Studies International, 37, pp. 4-33.

\section{PRICE Richard}

1991 «Subsistence on the plantation periphery: crops, cooking, and labour among eighteenth-century Suriname Maroons » in Ira Berlin and Philip D. Morgan, eds, The slaves' economy, Frank Cass, London, pp. 107-127. 
2001 "The miracle of creolization : a retrospective », New West Indian Guide, 75, pp. 35-64.

RASHFORD John

2001 "Those that do not smile will kill me: the ethnobotany of the ackee in Jamaica ", Economic Botany, 55, pp. 190-211.

REDField Robert, Ralph Linton and Melville HeRskovits

1936 "Memorandum for the study of acculturation », American Anthropologist, 38 , pp. 149-152.

Richards Audrey

1939 Land, labour, and diet in Northern Rhodesia, Oxford University Press, London.

Rouse Carolyn and Janet Hoskins

2004 «Purity, soul food, and Sunni Islam : explorations at the intersection of consumption and resistance ", Cultural Anthropology, 19, pp. 226-249.

\section{ScotT David}

1991 "That event, this memory: notes on the anthropology of African diasporas in the New World ", Diasporas, 1, pp. 261-284.

1999 Refashioning futures, Princeton University Press, Princeton.

ScotT Rebecca J.

1985 Slave emancipation in Cuba : the transition to free labor, 1860-1899, Princeton University Press, Princeton.

Segre Roberto, Mario Coyula and Joseph L. Scarpaci

1997 Havana : the two faces of the Antillean metropolis, Wiley and Sons, Chichester.

SHERIDAN Richard B.

1976 "The crisis of slave subsistence in the British West Indies during and after the American Revolution ", William and Mary Quarterly, 33, pp.615641 .

SLocum Karla and Deborah A. Thomas

2003 "Rethinking global and area studies : insights from Caribbean anthropology ", American Anthropologist, 105, pp. 553-565.

SMITH Michael G.

1965 The plural society in the British West Indies, University of California Press, Berkeley.

SPIVEY Diane M.

1999 The peppers, cracklings, and knots of wool cookbook : the global migration of African cuisine, State University of New York Press, Albany.

STRATHERn Marilyn

1995 "The nice thing about culture is that everyone has it », in Marilyn Strathern, ed., Shifting contexts, Routledge, London, pp. 153-176. 
StUTZMan Ronald

1981 «El mestizaje : an all-inclusive ideology of exclusion », in Norman E. Whitten, Jr., ed., Cultural transformations and ethnicity in modern Ecuador, University of Illinois Press, Urbana, pp. 445-494.

Swarns Rachel L.

2004 "African-American" becomes a term for debate ", The New York Times, August 29 (national edition), pp. 1, 14.

SZWED John F.

1974 «An American anthropological dilemma : the politics of Afro-American culture », in Dell Hymes, ed., Reinventing anthropology, Vintage, New York, pp. 153-181.

TAussig Michael

1989 " History as commodity in some recent American (anthropological) literature ", Critique of Anthropology, 9, pp. 7-23.

THORNTON John K.

1984 "The development of an African catholic church in the kingdom of Kongo, 1491-1750 », Journal of African History, 25, pp. 147-167.

1988 "On the trail of voodoo : African christianity in Africa and the Americas ", The Americas, 44, pp. 261-278.

1992 Africa and Africans in the making of the Atlantic world, 1400-1680, Cambridge University Press, Cambridge.

2002 "Religious and ceremonial life in the Kongo and Mbundu areas, 15001700 ", in Linda Heywood, ed., Central Africans and cultural transformations in the American diaspora, Cambridge University Press, Cambridge, pp. 71-90.

Tornero Tinajero Pablo

1996 Crecimiento económico y transformaciones sociales : esclavos, hacendados y comerciantes en la Cuba colonial (1760-1840), Ministerio de Trabajo y Seguridad Social, Madrid.

Troullzot Michel-Rolph

1992 "The Caribbean region : an open frontier in anthropological theory ", Annual Review of Anthropology, 21, pp. 19-42.

2002 "Culture on the edges : Caribbean creolization in historical context », in Brian Keith Axel, ed., From the margins : historical anthropology and its futures, Duke University Press, Durham, pp. 189-210.

VANSINA Jan

1990 Paths in the rainforest : toward a history of political tradition in Equatorial Africa, University of Wisconsin Press, Madison.

Villapoll Nitza

1977 "Hábitos alimentarios africanos en América Latina », in Manuel Moreno Fraginals, ed., África en América latina, UNESCO, Paris, pp. 325-336.

WADE Peter

1993 " "Race", nature, and culture ", Man, 28, pp. 17-34. 
Weiss Brad

1996 The making and unmaking of the Haya lived world, Duke Universty Press, Durham.

WALKer Clarence E.

2001 We can't go home again : an argument about Afrocentrism, Oxford University Press, New York.

White Hayden

1973 "The value of narrativity in the representation of reality », Critical Inquiry, 7, pp. 5-29.

WiLliams Vernon J., Jr.

1996 Rethinking race: Franz Boas and his contemporaries, University Press of Kentucky, Lexington.

Williams-Fortson Psyche

2001 "'Suckin” the chicken bone dry' : African American women, fried chicken, and the power of a national narrative ", in Sherrie A. Inness, ed., Cooking lessons, Rowman and Littlefield, Lanham, pp. 169-191.

Yelvington Kevin

2001 "The anthropology of Afro-Latin America and the Caribbean : diasporic dimensions ", Anmual Review of Anthropology, 30, pp. 227-260.

Zeven Anton C. and Petr M. Zhuкovsкy

1975 Dictionary of cultivated plants and their centers of diversity, Centre for Agricultural Publishing and Documentation, Wageningen. 